\title{
Commentary
}

\section{The Cosmopolitan, the Local, the Particular, and the Universal: Commentary on Nahal Naficy's "From Rice University to the University of Tehran"}

\section{Cristiana Bastos}

University of Lisbon, Portugal

I would like to start with a note of praise for the World Anthropologies section of American Anthropologist for providing the opportunity to discuss the varied forms, styles, contents, and practices of the discipline around the world, as in Nahal Naficy's case study of her encounters with anthropology in Iran after training in the United States. Naturally, each case presented in the World Anthropologies section reenacts the structural tension between what is particular and what is widely shared, general, and perhaps universal. That tension emerged in my reading of Nacify's essay.

My first reaction to the essay was to wonder how much of Nacify's experience in joining the Anthropology Department in Tehran was site-specific or very similar to that of anyone joining a department anywhere, abroad or at home. Any new faculty member anywhere can be asked to fill an empty slot and teach according to the department's needs rather than on matters of her or his specialty, uniqueness, and ambitions. Any first job can be a terrain of tensions between the joys of getting a position that may lead to professional fulfillment and the frustrations of being removed from the path to theoretical immortality imagined in graduate school. To that point, the author's experience may have been shared by many others transitioning from life as a graduate student to that of faculty.

But the transition narrated by the author was not just any transition, nor was it simply a return home, as Naficy, her world, and her home had all been transformed while she was in the United States. Nacify provides a guide to the precise conditions of the setting (the University of Tehran) and of her expectations so that we can assess the specificities of this particular locale of anthropology as she, a young cosmopolitan anthropologist with a particular background, has experienced it. Naficy's postreflexive take on ethnography - "what anthropologists do" - clashed with a local devaluation of long-term, field-based ethnography as a backward method associated with things past, unable to compete with the more attractive "grounded theory" proposed by sociologists. In sum, at her arrival in Tehran, sociology was cool and anthropology was backward.

The author creatively overcame such estrangement by settling in science and technology studies (STS), an indisputably cool disciplinary niche where, at the time, much theoretical innovation was happening. But, yet again, there were the particularities of time and place, and STS had to be negotiated in local terms, such as Iran's appraisal of science as a banner of modernity. Naficy had to juggle STS in the structural tension, lived there as elsewhere, between what STS anthropologists like to do and what science institutions require them to do.

In addition to those tensions, the author experienced the stress of having to accomplish much in a short time; again, this is a universal condition, yet experienced and enacted in particular tones such as the constant blogging Naficy's position required. Those circumstances removed from the author's immediate horizon the prospect of fulfilling a personal project. But the worst was yet to come. It arrived as the suspension from her functions, and for unclear reasons.

If the author had ended the narrative at this point, we might be prompted into fast and fragile appreciations of what anthropology in Iran is and is not. Fortunately, the essay covers a larger span of time and a variety of experiences that in one way or another relate to anthropology in Iran. After the interruption of her activities at the University of Tehran, Nacify went abroad and pursued a research project on the topics she had cherished for a long time but had no chance of fully exploring while she was teaching and blogging. She settled in Berlin, away from the incidents and frustrations of Iranian domestic politics, away from the specificities of her original doctoral program, and closer to the experience of a disembodied, universalist, and cosmopolitan practice of working in theory.

When she returned to Tehran, she had changed, the world had changed, and the anthropological landscape was rapidly changing. The students were pushing research agendas forward, campus life was in transformation, reading groups took shape, and the prospect of a theory-friendly anthropological niche was there. Anthropology in Iran is dynamic after all, and the narrator is part of those dynamics.

Naficy's experience is well narrated; the author uses her ethnographic skills to provide detail and description, indexing the universal embedded in the particular. Her experience will not be replicated in other settings, or at least not exactly in the same terms. It will not provide the basis to formulate a universal law. But it will shape our knowledge, awareness, and ability to recognize complexities, structures, articulations, and indeed human agency. Just like ethnographies do.

Nahal Naficy's experience described in this essay resonates only very partially with my own experience of returning home to Portugal after years of training in the United States at the CUNY Graduate Center. Much in her experience sounds familiar: juggling different academic agendas, moving from an academic vanguard into what used to be home and yet had changed in the meantime, facing puzzlements and alienation, finding creative responses and new 
approaches, building different networks with new partners, changing focus, and so on. But as much as I went through some of these universal stances, I also had the good fortune of having met with different particularities of context: same structure, different contingencies, different experience. While I was away in the United States into the mid-1990s, things at home changed dramatically - and for the better, as far as higher education goes. The country had joined the EU. The democratic regime had matured (a dictatorship had lasted until the mid-1970s, inhibiting the development of the social sciences). There was, among many positive developments, much more funding for science and a public commitment to enhancing the scientific infrastructure. Furthermore, the social sciences were taken seriously, much to the benefit of the anthropological community. I thus had the privilege of working in an environment where programs expanded, graduate students were funded, research projects received support, and the discipline gained credibility. Those were my particulars, which every now and then have replicas in other situations (like Brazil in the mid-2000s) but cannot be taken as universals.

What was yet to come, however, may resonate more universally. What was lived as commitment to expand and strengthen research institutions and a political choice of investing in higher education is now challenged by the managerial ideologies that seemingly pervade every institution, turning education into a business with consumers, providers, and products; turning labs into sweatshops producing repetitive outcomes; bringing an insidious precariousness to most academic appointments - all standing upon an alliance of austerity and auditing that leaves little resources and energy to actually pursue research and practice higher education. Regardless of the particular configurations this trend takes locally, the pattern is widespread. Perhaps the World Anthropologies section is a good site to share the modes of resistance that are already in place - be it in Tehran, Lisbon, Brussels, Johannesburg, Rio, or Berkeley. A challenge for a next chapter?

\section{Commentary \\ Remaking the Craft: Reflections on Pedagogy, Ethnography, and Anthropology in Iran}

\section{Orkideh Behrouzan}

SOAS University of London

I would like to thank American Anthropologist for inviting these reflections and Nahal Naficy for her candid ethnographic account of the possibilities, promises, hopes, and institutional blockages in the disciplinary life of anthropology in Iran. Her nuanced portrayal of the difficulties of doing ethnographic work in Iran is itself a welcome and timely piece of ethnography that shows how one can persevere in an ethnographic calling against all odds. Her paper complements other informative insights into the history and the state of the discipline in Iran (Fazeli 2006; Hegland 2009; Manoukian 2011; Nadjmabadi 2009). It is in this history that Naficy's 2009 return to Iran and her reflections on the state of pedagogy and methodology should be situated. Her piece raises questions about reflexivity and Otherness in a climate already marked by generative debates about the stakes of anthropology and how its boundaries are defined in relation to changing ideological territorializations. Not only is the piece an invitation to Iranian anthropologists and anthropologists of Iran to rethink pedagogy, but it is also a call to take seriously the question of disciplinary identity.

One has to rewind the clock back to the 1960s debates on colonialism and cultural identity, the flourishing of folk studies that helped plant the seeds of an indigenous anthropology in the 1970s, followed by the legacies of the 1980-1983 Cultural Revolution in order to contemplate the fate of anthropology in the decades that followed the 1979
Revolution (Fazeli 2006; Hegland 2009; Nadjmabadi 2009). Today's preoccupation of Iranian social sciences with notions of modernity, development, cultural identity, and critiques of "Western" ideologies is rooted, in part, in these historical moments. In the 1960s and 70s, several non-Iranian anthropologists, notably Byron Good, Mary Jo Good, Michael Fischer, William Beeman, Mary Elaine Hegland, Richard Tapper, Mary Catherine Bateson, and several others joined their Iranian colleagues in Iran (including Mehdi Soraya, Sekendar Amanollahi, Fereydoun Safizadeh, Kaveh SafaIsfahani, and Soheila Shahshahani, among others) and created seminal ethnographic texts (see Hegland 2009). Several of these ethnographies not only impacted the trajectory of American (US) anthropology in the 1980s but also rendered Iran one of the birthplaces of what has now become the established field of medical anthropology. ${ }^{1}$ The predominantly interpretive approach of this cohort acknowledged the 1960s debates on cultural authenticity and created a marriage of phenomenology, cultural analysis, cultural critique, and indigenous anthropology. But this work was interrupted by the 1979 Revolution and the 1980-1983 Cultural Revolution, which shut down universities and sought to purge from the academy all that contradicted the ethos of the revolution, including Westernized teachings and teachers.

The pedagogical impact of the Cultural Revolution on different disciplines was uneven (see chapter 2 in Behrouzan 2016). Eventually, the more "scientific" and "professional" disciplines (namely, medicine, basic sciences, and engineering) were mostly spared from major curricular 